\title{
Chaos, Disorder and Apocalypse: W. B. Yeats' The Second Coming vs Amal Donqol's The Coming Testament
}

Amr Nassar Mohamed Abdallah ${ }^{(*)}$

\begin{abstract}
This paper aims at presenting a semiotic analysis of W. B. Yeats' The Second Coming and Amal Donqol's Chpater Three, The Book of Genesis from his Collection The Coming Testament, through using Michael Riffaterre's terms of hypogram, ungrammaticalities, indirection and the matrix. This paper is part of an M.A. thesis entitled Semio-Linguistic Codes in the Poetry of W. B. Yeats and Amal Donqol: a Comparative Study. This study depicts the similarity and difference between both poets in style, technique and themes.

Key Words: Yeats, Donqol, The Second Coming, The Coming Testament, Semiotics, Riffaterre.

\section{Introduction}

The similarity between the two works is astonishing. Both expose the disorder and chaos in the world. The Third chapter of the Book of Genesis is very much like the first stanza of Yeats' poem. As Yeats, Donqol finds modern world torn

(*) Demonstrator, English Department, Faculty of Arts, Sohag University.

This paper is part of an M.A. thesis entitled "Semio-Linguistic Codes in the Poetry of W. B. Yeats and Amal Donqol: a Comparative Study", Supervised by Prof. Prof. Bahaa-eddin M. Mazid, Acting Dean, Faculty of Al-Alsun, Sohag University \& Dr. Ismail A. Ahmed, Chair, Department of English, Faculty of Arts, Sohag University.
\end{abstract}


between dark and light, death and life, and freedom and slavery. Doqol sees that this destruction will reach animals, birds and even inmates, while Yeats presents animals, birds in particular, as horrible creatures. The basic difference between Donqol and Yeats in these poems is that Yeats is more pessimistic believing that the end of the world is coming as part of his belief in the gyre of civilization, while Donqol refers to those who cause the chaos and disorder in order to end them. They are the usurer, the feudalist and the people who get rich by war. What distinguishes Donqol's poem from Yeats is that Donqol puts the responsibility of the chaos on authority. He does not share the attitude of intellectuals towards authority as merely an oppressive power, but he looks deeper making it responsible for the destruction of humanity (El-Dosary 1991, 176). Thus, Donqol's can be attached to political situations while Yeats' remains more universal.

\section{The Second Coming}

\section{Summary}

The speaker describes a disturbance scene; the falcon is turning in a wide gyre and cannot hear the falconer. The falcon should not keep turning in gears. It should stop and go back to its master. The speaker declares that everything is falling and the center cannot hold. The speaker, then, mentions the consequences of this anarchy. Anarchy spread around the world, blood, like water, is loosed everywhere, and innocence is over. He states that the best people lack all convictions, while the worst are passionate. It seems that everything is 
strange working the opposite way. One can assume that no one can tell the difference between the good and the bad. After that, the speaker declares that the second coming is at hand; it will happen soon. He even repeats the sentence. So, one asks about the second coming and whether this is going to end such chaos or not. The speaker refers to 'Spiritus Mundi', which means the spirit of the world. The speaker tells a vision in the desert about a sphinx, which is described with pitiless and blank gaze. This sphinx seems to have no compassion with humans. It is indifferent towards them, and moves slowly towards them. The vision of Spiritus Mundi ends, and darkness comes again. He refers to the birth of the Christ which was twenty centuries ago. A beast is about to be born, a rough one as the speaker assures. It will be born in Bethlehem where the Christ was born.

\section{Analysis}

The poem is about chaos and anarchy in the world. It is not only one of Yeats' most famous poems, but one of the most famous of English literature. It is ambiguous full of rough images and disturbance rhythm. It predicts what is going to happen what Yeats calls the "second coming". It is about Europe after World War I, where everything was confused, no one could tell the difference between right and wrong and it seemed that another war was coming. The first hypogram one meets is the title-The Second Coming, which refers to the Book of Revelation in the Bible. It is also known as the "Apocalypse". It is full of violent images, speaking about the end of the world. In addition to that hypogram, he uses the fifth 
line as a hypogram for Noah's flood: “The blood-dimmed tide is loosed upon the world", in which he replaces water by blood. The sphinx is another hypogram referring indirectly to the Bible. As the Sphinx which is Egypt brings to mind when Jews waited for Prophet Moses to leave Egypt. They waited for a prophet to come, as in the poem, people are waiting for the second coming of the Christ. Moreover, one can argue that there are two actual hypograms; the first one is in the seventh and eighth lines when the speaker says: "The best lack all conviction, while the worst are full of passionate intensity", since it refers to a famous quote by English philosopher Bertrand Russell which he said after WWI: "the whole problem with the world is that fools and fanatics are always so certain of themselves, and wiser people are full of doubts". Yeats was interested in philosophy, and perhaps he came through Russell's quote. Perhaps it is confusing that Yeats uses all these hypograms from the Bible, but opposing the Bible that the second coming is not by the Christ but by the Anti-Christ. Yeats "developed his own religion", he uses hypograms and references from different resources (Canfield 2012, 227). The second actual hypogram is "stony sleep" which refers to William Blake's Book of Urizen. William Blake made a prophetic book as a parody of the Book of Revelation, and his major character was Urizen, who was a priest alienated from others and decided to make his own 'religion'. William Blake writes:

"But Urizen laid in a stony sleep

Unorganized, rent from eternity" 
The structure is not very much complicated, yet the images, the juxtaposition and the rhythm are hard to follow. The first stanza shows the current situation of the world; it is full of chaos and anarchy. The second one refers to the coming of a new Christ, not the Christ one knows but a rough beast. Yeats believed that history had cycles and gyres, and a new one was about to come. This appears in many of his poems, for instance, in Leda and the Swan, he argues that the world is about having a new era after the act of rape. Therefore, in The Second Coming, he believes it is the time for a new gyre. Yeats seems to divide history into different eras: he referred to the era after the rape of Leda, followed by the era of the Christ, and the world is waiting for a new era (ibid: 233). Canfield illustrates that Yeats believed in what he used to call "interchange of the tinctures", i.e. that every two thousand years religion changes "from antithetical in quality or vice versa" in the same time "secular life and politics change tinctures just oppositely" (ibid: 235-36). The poem, thus, illustrates the conflict between modern world and brutal world, and between secularism and religion. The disturbing rhythm serves to deliver the disturbance in the outside of the poem. Yeats wants the reader to be shocked of the chaos and disturbance to make connection between the text and the real world. Form the very beginning, the speaker says "the falcon cannot hear the falconer", which refers to the fall of a number of values, since such activity is attached with the noble class with all their traditions, and when the falcon does not hear his master, then masters, i.e. the noble class has lost its power. $\mathrm{He}$ 
uses gerund in the beginning of the poem "turning and turning" assuring the continuous status of the disorder.

He uses declarative sentences as in "Things fall apart, the center cannot hold", "surely the second coming at hand", "the ceremony of innocence is drowned", and "surely some revelation at hand". He uses one rhetorical question in the end if the poem, which is more like a declarative sentence, as he says in seventeenth line "but now I know", and the following lines show what he claims to know:

"And what rough beasts, its hour come round at last,

Slouches towards Bethlehem to be born"

As for the indirections in the poem, Yeats depends on displacing and distortion. The poem starts with a displacing in the first stanza "Turning and turning in the widening gyre/ the falcon cannot hear the falconer", which is not only an image of a bird, but also shows the gyre and cycle of history. In the second stanza, he presents a similar displacing image "Reel shadows of indignant desert birds", in which the desert birds also are turning around. Such images prove his belief in the cycle of civilization and history. He chooses the 'falcon' in the first stanza because it is supposed to be trained, yet it lost connection with its master. Then, he moves to the 'birds' which were described as "indignant" to make the reader feel the horror of the disorder. One asks if the falcon which is supposed to be under control is now errant what will be the case with the "indignant desert birds"? Therefore, one is shocked by the second coming expecting the end of civilization. There are other displacing images as in "anarchy is loosed", "blood- 
dimmed tide is loosed", "troubles my sight", and "A shape... is moving its thighs" which is extended metaphor; he starts it with a metonymy for the sphinx: "A shape with lion body and the head of a man". Yeats also uses distortion as in:

"That twenty centuries of stony sleep

Were vexed to nightmare by a rocking cradle",

Juxtaposition and irony are basic in the structure of the poem; juxtaposition exists: between chaos and order, between history, present and the future, between civilization and primitivism, between innocence and brutality, between right and wrong, between secularism and religion, and between the real Christ and Anti-Christ. It is ironic to use Bethlehem to refer to the Anti-Christ, where the Christ was born. Perhaps the speaker is referring to the Christ himself as a beast, since Yeats in 1920s and 1930s started to be a big fan of Marxism and Fascism which do not acknowledge religion so much.

The matrix of the poem is the state of chaos and disorder. It is what governs the poem from the images to rhythm to ambiguity in the meaning. Yeats wants to show the disorder of the world after WWI, and expects that a more chaos is coming. He believes in the cycle of history and civilization. Moreover, he is not very much optimistic about the new change of the world. There is a paradox in: "the best lack all conviction, while the worst/ Are full of passionate intensity" which illustrates the state of chaos in the world. 


\section{Chapter Three, Book of Genesis, The Coming Testament}

\section{Summary}

The poem is a description of chaotic and disordered life, where all the noble values are collapsing. The speaker asks for love to be spread in earth, but it does not happen. He wishes if it the river could dissolve in the sea to make rains so that the hungry people could plant their lands. As man cares only about his interest that he builds fences and bring guards to protect his farm and sell to his fellow men bread and water. Love exists only for those who can afford it, and that God does not like the corruption man does. The speaker then asks for justice, and wonders if other creatures kill their own specie as man does; a wolf does not kill a wolf and a sheep does not kill a sheep. Yet, man can kill another man, can burn cities, or even cut open pregnant women. The only measure for justice is gun and those who defend justice are crucified or hanged. The speaker illustrates that he had asked for justice but it belongs only to those who are attached to the regime, and God also does not like what is doing. After that, the speaker asks for reason arguing for balance. He adds that birds do not build their nests in a snake's mouse and warms do not live near fire. However, man destroys his own home: he cuts trees, corrupts well, throws oil in the river, and even puts death bomb under his own house. Man devises his children seditions in addition to his name and religion. Moreover, reason became a strange person thrown with stones by young children, stopped by soldiers in boards, and listed in of home haters. The speaker 
assures that he wished for reason, but reason has fallen in the cycle of prison and exile till it lost its reason, and God disliked what man has caused with reason.

\section{Analysis}

The coming Testament is Donqol's vision the modern society, a society where the main values of humanity have destroyed by man. Chapter three in the Book of Genesis focuses mainly on the corruption Man has done to earth contradicting of what he is supposed to do. Donqol creates a collection of poems disguised as a holy book named after the Old Testament and the New Testament. He divides his 'testament' into books, chapters and psalms. Chapter three is divided into three parts, each dealing with a basic human value: love, justice and reason. The chapter depicts how each of the three values has been destroyed by man himself which is against the will of God.

The whole collection is a hypogram for the old Testament, and of course this poem is a hypogram for the original Book of Genesis in the Bible. In fact, Book of Genesis mentions how God is not satisfied with man's behaviors and confirming that it is man' responsibility for the such destruction. So is Donqol's book; it puts the blame on man, yet it refers to God as someone only watching "'And God saw this was not good"", which showing God as a negative authority. Donqol had problems with any representation of authority. He sees authority as an oppression power. Donqol depends on actual hypograms in the structure of the sentences, he follows 
the Biblical structure as he says: "Let love be on earth", "let justice be on earth", and "Let reason be on earth", while The Bible mentions for instance: "And God said, "Let the waters bring forth swarms of living creatures, and let birds fly above the earth across the dome of the sky". Moreover, Donqol puts himself in the place of God as he mentions "I said", which suggests that he is making his own testament paralleling with God's testament, reversing the role of God merely an observer. Yet, El-Reweny argues that his Testament is about "finding a new god in human wear". It is converting the heavenly "absolute" power form the hands of one authority to the experience and freedom of man (El-Reweny 1992, 25-26). In the later chapters of the book, good represented in the elements of nature will overcome the evil. Those elements are reflection of the lower "good" classes and the revolutionists. In all of his poems, he believed in revolution as a solution to end the tyranny. Donqol's Book of Genesis introduces the "conflict" between two different situations, i.e. "what exists and what should be" relying on the "rational and social levels" (Eisha 2009, 599). One can add that also he uses a hypogram from Arabic heritage which "An eye for an eye..A tooth for a toth", which asks for the complete justice.

The ungrammaticalities of the poem are shown in the use of juxtaposition, irony and parallel structure. Juxtaposition exists between ideas and sentences; each part introduces a basic value of humanity and the case when it disappears, creating a state of juxtaposition in each part for instance, it exists between love and the disappear of love, justice and 
injustice, and reason and the lack of reason. These ideas of juxtaposition are illustrated in sentences in each part, for example in the first part, the speaker says:

"I saw the son of Adam

Raising his fences around God's personal farm

Shopping for border guards

Selling bread and water to his brethren

Milking lean cows"

This extract juxtaposes with the previous verse in which he says: "Sprouting bread to sustain hungry hearts"; it is a juxtaposition between what happens in the world and what should happen, and moreover between love and caring and the disappearance of love. Man has lost empathy towards his fellow man. In the second part, there is a juxtaposition between justice and injustice, and also between what justice should be and the current status of justice; the speaker mentions:

"Justice become death

The gun its measure

Its children crucified in public squares and city street corners"

This is juxtaposing with the first sentence of the part "an eye for an eye...a tooth for a tooth", it is a painful juxtaposition, as the speaker does not only declare the absence of justice as in in "And I came to see the son of Adam..slaughtering the son of Adam", and "setting fire a blaze", but also declares that those who defend justice are either hanged or crucified. It is a complete situation of injustice. In the third part, the speaker repeats a similar juxtaposition, referring to logical axioms existing in nature like where the birds or warms live: 
"Do birds build nests in a snake's mouth?

Do worms live in fiery flames?

Does the owl paint its eye-lashes black with Kohl?"

The speaker shows how nature works which are basic rules of logic and rational, yet man loses his reason causing his own destruction by destroying the environment, and such acts of man result in the absence of any kind of rational making reason a strange act of behavior:

"I saw the son of Adam go mad:

Uprooting tall trees

Spitting in wells

Spilling oil on the face river's face

Living in a house while storing a deadly bomb

Under the sill"

Donqol depends on parallel structures and repetition. The poem is divided into three parts, each is paralleling the other: each starts with a wish of a basic value to exist (love-justicereason), explaining what man has done with such value, and ending with the consequences of his acts. Each starts with "I said" referring to the value followed by another "I said" explaining why this value is important. Then the speaker repeats in each part "I saw the son of Adam", in which he explains what man causes to the value he speaks about. The speaker ends each part by repeating the essential value he asked for and repeating God's attitude towards man' behaviors by repeating "And God saw this was not good". Parallel structures also exist in the same part as in the first part he says 
"Let river dissolve into ocean..ocean into drought..drought into fertility?" In the second part, there is a parallel structure between "Does the wolf devour a wolf?.. The goat devour a goat?", and in the third part it also exists in: "Do worms live in firey flames? Does the owl pant its eye-lashes black with kohl?".

The poem is ironic in the sense that man does everything he can do to destroy himself. He does exactly the opposite of he is supposed to do being blind by his greed and insanity. In the first part, the speaker says: "Milking lean cows to give milk", in the same times he brings guards and building fences only to protect himself. It is ironic that man turns to be selfish and the only love he has is for himself or for those who can afford to pay the price. It is again ironic that man turns an intelligible value like love has a price. In the second part, it is ironic that man kills his fellow man while the wolf does not. Moreover, it is ironic that the measure of justice is the gun not the right or wrong. In the third part, it is ironic that other species like birds, warms and owls have logic while man who is supposed to have the logic and reason does not have any.

As for the indirection, the poem depends on displacing represented mainly in personifications metaphors, and metonymies. Each part presents an extended personification of a certain value: the first part is extended personification of love, in the second of justice and in the third of reason. Each extended personification has some personifications as for example. "His patriotic identity invalidated by governments" and "Arrested by border guards". There are metonymies as in 
"His shirt of strife" and "The gun its measure."All the images show the disorder and chaos of the current life of man.

The matrix of the poem is what man does against what he should do. It is the chaos and disorder overwhelming the life of man. Man destroys the basic values of humanity he needs to live. In addition to that, he makes all the values of love, justice and reason alien to his culture, and punishes those who adapt such values. It seems that man turns from someone capable of "establishing goodness and justice" to a "power" that has no morals as (Eisha 2009, 599).

\section{Conclusion}

Donqol depicts what causes such chaos and disorder which is the absence of love, justice and reason, and therefore, if such values are back, the disorder will end. Yeats does not depict the reasons of the disorder, he just describes the current situation. For him, the second coming and the end of the world are inevitable. Moreover, it seems that Donqol' testament has a political reference accusing the regime which is supposed to save the values of love, justice and reason of destroying such values. While in Yeats', there is no clear accusation of any regime. Yeats even does not accuse man directly of the state of chaos; he only declares that this case is in control of the world now.

One can add that Donqol introduces similar gyres of history as Yeats does. There are three basic values in Donqol's Testament which are love, justice and reason. Perhaps Donqol refers to three gyres of human history which are Christianity, 
Islam and modern life. Christianity basic value is love; Islam basic one is justice and modern world is based on science and reason. It seems that he wants to declare the fall of each gyre because of the corruption of man and the oppression of authority, and that is why the world needs a new Testament. He even adds in the fourth chapter of the Book of Genesis: "Let the wind sweep this decay", in which he assures that all such chaos and disorder will end.

\section{Works Cited}

- Canfield, Rosemary M. (ed). Critical Survey of Poets: Irish Poets. Massachusetts: Salm Press, 2012.

\section{Arabic Works Cited}

أحمد الدوسري. أمل دنقل: شاعر على خطوط النار. القاهرة: دار الغد،

El-Dosary, Ahmed. 1991

عالة الرويني: الجنوبي. الكويت: دار سعاد الصباح، 1999 ال.

Reweny, Abla.

علي مصطفى عشا: البعد الثوري في شعر أمل دنقل. دراسات العلوم

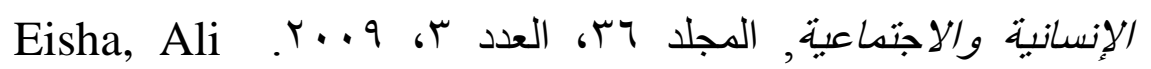

Mustafa. 